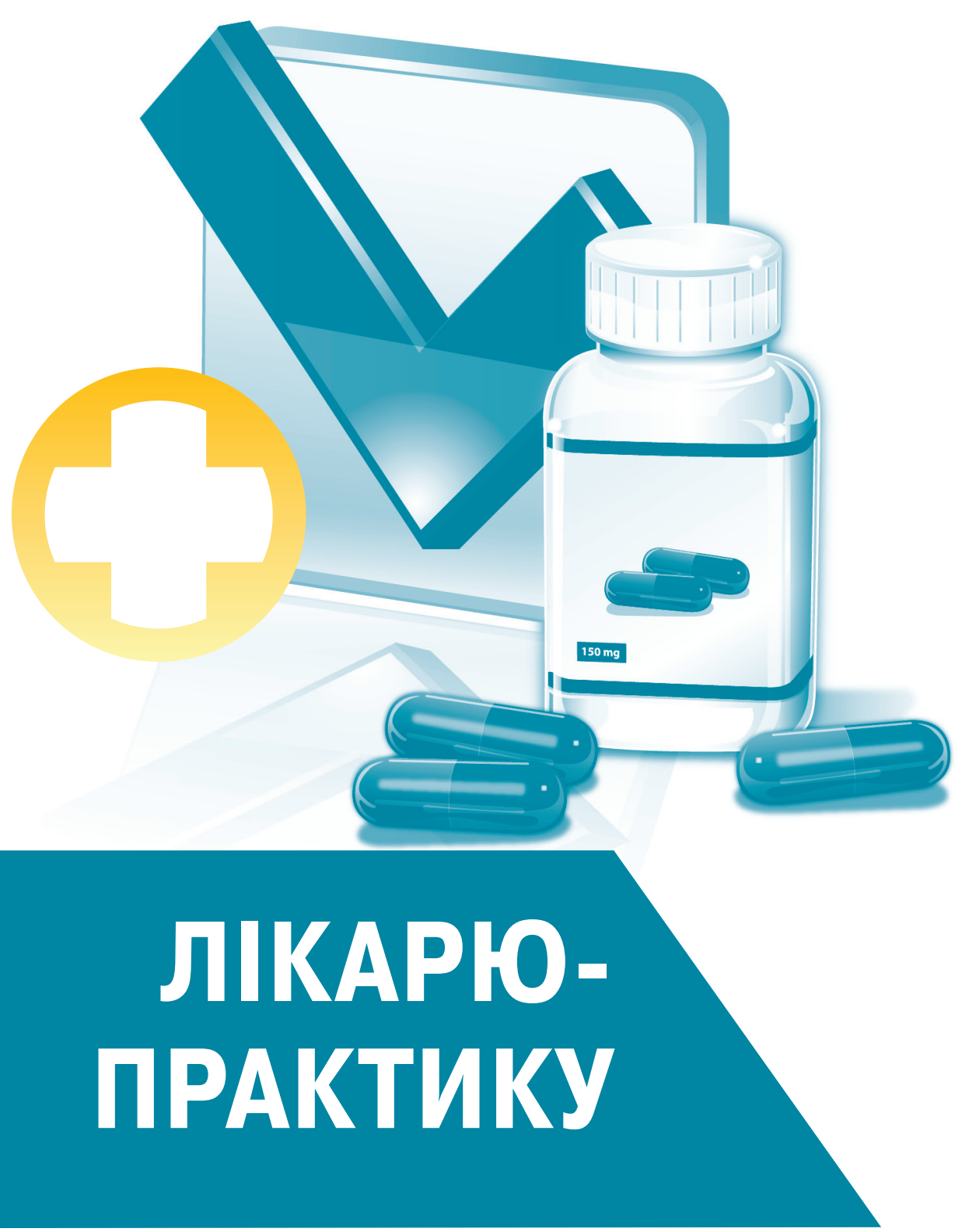

Вплив індивідуальних особливостей організму, патологічних процесів, комбінованого застосування лікарських засобів на їх ефективність О роли низкоуглеводной высокожировой диеты в лечении и профилактике сахарного диабета и ожирения......

Печеночные пробы: обновленные рекомендации. 


\section{Вплив індивідуальних особливостей організму, патологічних процесів, комбінованого застосування лікарських засобів на їх ефективність}

Аналізуються причини зниження (відсутності) ефективності лікарських засобів: генетично зумовлені особливості пацієнта, вплив коморбідних патологічних процесів, наслідки взаємодії лікарських засобів при їх комбінованому застосуванні, їх взаємодії з харчовими продуктами, вплив тютюнопаління, резистентність інфекційного збудника до антимікробного препарату.

Ключові слова: лікарські засоби, відсутність ефективності.

Одним із небажаних результатів призначення лікарськихзасобів є відсутність очікуваного ефекту від їх застосування (відсутність ефективності лікарських засобів) - неспроможність лікарського засобу зумовити фармакологічнудіюуразі, якщойогопризначеннядля лікуваннячи профілактики захворюваньздійснюється згідно зінструкцією для медичного застосування (Матвєєва О., Яйченя В., 2014).

Відсутність ефективності (ВЕ) лікарського засобу може виникнути з багатьох причин. Наприклад, це може бути результатом неналежного застосування лікарського засобу, коли препарати призначаються не запоказаннями (антибактеріальні антибіотикипри вірусних захворюваннях, аміноглікозиди при легкому перебігу позалікарняної пневмонії тощо), порушення схем дозування лікарського засобу і тривалості лікування, ігнорування впливу коморбідних патологічних процесів (серцево-судинної недостатності, ожиріння, алкоголізму), генетично зумовлених особливостей пацієнта, неврахування наслідків взаємодії лікарських засобів при їх комбінованому застосуванні, особливо за наявності поліпрагмазії, взаємодії лікарських засобів із компонентами їжі, впливу тютюнопаління (Белоусов Ю.Б., Гуревич К.Г., 2005). На особливу увагу заслуговує така причина ВЕ лікарських засобів, як відсутність чутливості інфекційного збудника до антимікробного препарату.

Незважаючи на те що застосування лікарських засобів у наш час ґрунтується на засадах доказової медицини, у багатьох випадках ефективність фармакотерапії, за даними ВОО3, не перевищує 60\% (Журавлева М.В. и соавт., 2015). Серед інших факторів генетичний поліморфізм розглядається як одна з ключових причин різної інтенсивності відповіді організму на введення лікарських засобів. Зокрема, застосування антигіпертензивних лікарських засобів лише у $30-50 \%$ пацієнтів супроводжується досягненням цільового рівня артеріального тиску (Яковлева О.О. та співавт., 2011). Діяпсихотропнихлікарських засобів значною мірою залежить від генетичних особливостей організму (Kempin S.J., 1983; Иванов А.М. и соавт., 2010а; б). Поліморфізм гена, що забезпечує глюкуронування опіоїдних анальгетиків, може статипричиноювідсутності терапевтичноїефективностіморфінуу $30 \%$ пацієнтів, які отримують його з метою знеболення (Боброва О.П. и соавт., 2017). Ефективнадоза варфаринуколиваєтьсяумежах 0,7-9,8 мг (Барышева В.О., Кетова Г.Г., 2016). У 20\% випадків застосування клопідогрелю його антиагрегантний ефект не проявляється, що потребує призначення іншого препарату (Барышева В.О., Кетова Г.Г., 2016). На ефективність лікарських засобів також суттєво впливає генетична варіабельність їх фармакокінетики (Белоусов Ю.Б., Гуревич К.Г., 2005; Кравченко І.А., 2005).

Роль генетичних факторів узменшенні (відсутності) дії лікарських засобів представлена утабл. 1 (Скакун Н.П., 1981; Seifi A. et al., 2004; Кравченко I.A., 2005; Hider S.L. et al., 2007; Зборовский А.Б. и соавт., 2008; Панчишин Ю.М., Якубенко Ю.П., 2011; Махарин О.А. и соавт., 2012; Садвакас А.С., 2014; МельникА.А., 2016; Food and Drug Administration US, 2016; Сидоренко И.А. и соавт., 2017).
Відповідно, для підвищення ефективності фармакотерапії та призначення лікарських засобів згідно з принципами персоналізованої медицини надзвичайно актуальним $є$ проведення фармакогенетичного тестування. Подібні тести вже розроблені та впроваджені у клінічну практику США, Канади, Австралії та країн Європи (Сычев Д.А. и соавт., 2009; Food and Drug Administration US, 2016).

Зниження ефекту деяких груп лікарських засобів (нітратів, адреноміметичних, снодійних лікарських засобів, особливо похідних барбітурової кислоти, транквілізаторів, опіоїдних анальгетиків тощо), як відомо, може бути наслідком виникнення толерантності чи тахіфілаксії при ї повторному застосуванні. Останнє $€$ результатом розвитку складних компенсаторних механізмів, зокрема змін фармакокінетики лікарських засобів, зниження/підвищення кількості та чутливості специфічних рецепторів, активності нейромедіаторнихсистем тощо (Белоусов Ю.Б., Гуревич К.Г., 2005).

На ефективність лікарських засобів може суттєво вплинути стан здоров'я пацієнта, зокрема наявність супутніх захворювань та їх дія на фармакокінетику лікарських засобів. Так, при застійній серцевій недостатності спостерігається порушення всмоктування в шлунковокишковому тракті та сповільнення секреції в ниркових канальцях

Таблиця 1. Роль генетичних особливостей організму у зменшенні (відсутності) дії лікарських засобів

\section{Зменшення/}

відсутність ефекту

лікарських засобів

Варфарин та інші

непрямі антикоагулянти

Ацетилсаліцилова

кислота, клопідогрель

Перекис водню

Такролімус

Інгібітори ангіотензин-

перетворювального

ферменту

Ондасетрон

Клозапін

Андрогени

Бусульфан

Капецитабін

Вазопресин

Статини

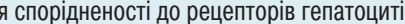

Поліморфізм у гені тромбоцитарного рецептора фібриногену (ITGB3)

Акаталазія

Підвищена активність цитохрому P450 3 А5

DD-генотип поліморфізму гена ангіотензинперетворювального ферменту

Підвищена активність цитохрому P450 2D6

Поліморфізм генів $5 \mathrm{HT}_{2 \mathrm{~A}}$-рецепторів

Інактивуючі точкові мутації в домені андрогенного рецептора Відсутність філадельфійської хромосоми

Дефіцит дигідропіримідиндегідрогенази Зниження чутливості вазопресинових V2-рецепторів у дистальних ниркових канальцях

ABCA1- чи АРОЕ-є3-генотип; експресія алеля цитохрому P4503А5; зниження активності білка - переносника ефірів холестеролу

Метотрексат $\quad$ Носійство алеля Т поліморфізму гена метилентетрагідрофолатредуктази (MTHFR C677T)

Морфін Препарати заліза Відсутність гена MOR-1, який кодує мю-опіатні рецептори

Вітамін D
Зниження рівня трансферину

Порушення утворення його активних метаболітів у нирках 
Таблиця 2. Фактори, що спричиняють зниження ефективності діуретиків (Зборовский А.Б. и соавт., 2008, зі змінами)

\begin{tabular}{|c|c|c|}
\hline Фактор & $\begin{array}{c}\text { Механізм зниження } \\
\text { ефективності }\end{array}$ & Шляхи подолання \\
\hline Ниркова недостатність & $\begin{array}{l}\text { Зменшення кількості } \\
\text { функціонуючих } \\
\text { нефронів }\end{array}$ & $\begin{array}{l}\text { Підвищення дози } \\
\text { та комбінування } \\
\text { діуретиків }\end{array}$ \\
\hline Нефротичний синдром & $\begin{array}{l}\text { Зв'язування діуретиків } \\
\text { білком сечі }\end{array}$ & $\begin{array}{l}\text { Підвищення дози, частоти } \\
\text { прийому в низьких дозах, } \\
\text { внутрішньовенне введення, } \\
\text { комбінована терапія }\end{array}$ \\
\hline Цироз печінки & $\begin{array}{l}\text { Механізм невідомий } \\
\text { (ймовірно, підвищений } \\
\text { рівень альдостерону) }\end{array}$ & $\begin{array}{l}\text { Підвищення дози, } \\
\text { частоти прийому } \\
\text { в низьких дозах, } \\
\text { комбінована терапія }\end{array}$ \\
\hline $\begin{array}{l}\text { Застійна серцева недостат- } \\
\text { ність (ступінь рефрактерності } \\
\text { зростає із підвищенням } \\
\text { тяжкості патології) }\end{array}$ & $\begin{array}{l}\text { Неповна і сповільнена } \\
\text { абсорбція }\end{array}$ & $\begin{array}{l}\text { Внутрішньовенне } \\
\text { введення, частий прийом } \\
\text { у низьких дозах, } \\
\text { комбінована терапія }\end{array}$ \\
\hline
\end{tabular}

Таблиця 3. Вплив серцевої недостатності на фармакокінетику деяких препаратів-проліків (Белоусов Ю.Б., Гуревич К.Г., 2005, зі змінами)

\begin{tabular}{lcc}
\multicolumn{1}{c}{ Препарат } & Всмоктування & Метаболізм \\
\hline Еналаприл & Знижене & \\
Лізиноприл & Сповільнене & \\
Цилазаприл & Знижене & \\
Раміприл & Знижене & Сповільнення утворення \\
Трамадол & Знижене & активного метаболіту \\
Лозартан & Знижене & \\
Клопідогрель & Знижене & \\
Кодеїн & Знижене & \\
\hline
\end{tabular}

Таблиця 4. Несумісність лікарських засобів при їх застосуванні в інфузійних розчинах (Белоусов Ю.Б., Гуревич К.Г., 2005, зі змінами)

\begin{tabular}{lcc}
\hline \multicolumn{1}{c}{ Лікарський засіб } & Несумісність & Причина \\
\hline Тіопентал натрію & Суксаметоній & Утворення осаду \\
Інсулін & Протамін & Зниження активності інсуліну \\
Гепарин & Симпатоміметичні аміни & Утворення осаду \\
& Тетрацикліни & Утворення осаду \\
& Аміноглікозиди & Утворення осаду \\
Гідрокортизон & Інактивація гепарину \\
Канаміцин & Гідрокортизон & Інактивація канаміцину \\
Пеніциліни & Гідрокортизон & Інактивація пеніцилінів \\
& Тетрацикліни & Утворення осаду \\
Тетрацикліни & Гентаміцин & Інактивація гентаміцину \\
& Пеніциліни & Утворення осаду \\
& Сульфаніламіди & Утворення осаду \\
& Гідрокортизон & Утворення осаду \\
Солі кальцію & Утворення осаду \\
Новокаїнамід & Цефалоспорини & Утворення осаду \\
Тіаміну бромід & Натрію гідрокарбонат & Утворення осаду \\
Вітамін В ${ }_{12}$ & Фуросемід & Утворення осаду \\
\hline
\end{tabular}

фуросеміду, що супроводжується підвищенням рівня його порогового ефекту. Інші причини, які сприяють розвитку толерантності до діуретиків, представлено у табл. 2.

При серцевій недостатності може змінюватися фармакокінетика і знижуватись ефективність лікарських засобів, що належать до групи проліків (prodrugs) та набувають фармакологічної активності в результаті метаболічних перетворень (табл. 3) (Белоусов Ю.Б., Гуревич К.Г., 2005; Яковлева О.О. та співавт., 2011).

Ще один патологічний процес, що може істотно вплинути на фармакокінетику лікарських засобів, - ожиріння. Відомо, що понад $30 \%$ мешканців Землі мають надмірну масутіла. При застосуванні у таких пацієнтів високо ліпідорозчинних лікарських засобів їх розподіл змінюється, відбувається накопичення препаратув жировій тканині, тому концентрація лікарських засобів у ділянці специфічних рецепторів може знижуватись із суттєвим зменшенням чи втратою фармакологічної активності лікарських засобів. У таких випадках необхідна корекція дозування або ж, як у разі застосування тіопенталу натрію - повторне введення препарату.

Зниження ефективності фармакотерапії може бути результатом фармацевтичної, фармакокінетичної та фармакодинамічної взаємодії лікарських засобів при їх комбінованому застосуванні, особливо при поліпрагмазії.

У табл. 4 наведено приклади несумісності деяких лікарських засобів при їх застосуванні в інфузійних розчинах.
У деяких випадках зниження фармакотерапевтичної активності лікарських засобів зумовлене його сорбцією на поверхні системи для внутрішньовенної інфузії, виготовленої з полівінілхлориду. Це явище описане для нітрогліцерину, ізосорбідудинітрату, ізосорбіду5-мононітрату, діазепаму, лоразепаму, мідазоламу, інсуліну, інтерферонів, аміназину, німодипіну, аміодарону, хлорметіазолу, хлорохіну сульфату, тіопенталу натрію, пропофолу, дипразину (Weir S.J. et al., 1985; Martens H.J. et al., 1990; Seifi A. et al., 2004; Thompson C. et al., 2012; Рэнки П.Дж. и соавт., 2014).

Взаємодія між лікарськими засобами може відбуватися на етапі всмоктування у шлунково-кишковому тракті, що також у деяких випадках супроводжується зменшенням вираженості фармакологічного ефекту (Белоусов Ю.Б., Гуревич К.Г., 2005) (табл. 5, 6). При цьому між лікарськими засобами можлива хімічна чи фізикохімічна взаємодія, порушення дії препарату внаслідок зміни рH шлунка. Зокрема, сукральфат не комбінують з антацидними засобами, інгібіторами $\mathrm{H}^{+} / \mathrm{K}^{+}$-АТФази чи з $\mathrm{H}_{2}$-гістаміноблокаторами, оскільки при зсуві рН у лужний бік суттєво зменшується його захисна дія. Якщо лікарський засіб всмоктується у кишечнику повільно (наприклад дигоксин), то його одночасне застосування із прокінетиками чи проносними препаратами може істотно знизити його ефективність (Самура Б.А. (ред.), 2009). Деякі ліки конкурують за транспортні системи тонкої кишки. Абсорбція і, відповідно, ефек-

Таблиця 5. Приклади зниження ефективності як результат взаємодії лікарських засобів на етапі всмоктування у шлунково-кишковому тракті (Белоусов Ю.Б., Гуревич К.Г., 2005, зі змінами)

\begin{tabular}{lcc}
\hline \multicolumn{1}{c}{ Препарат 1 } & Препарат 2 & Результат взаємодії \\
\hline Тетрацикліни & Препарати заліза & Пригнічення всмоктування 1 \\
Фторхінолони & Солі кальцію & $\begin{array}{c}\text { Утворення нерозчинних } \\
\text { комплексів 3 1 }\end{array}$ \\
& Алюміній-, магнійвмісні антациди & Зниження абсорбції 1 \\
H-гістаміноблокатори $_{2}$ & Антацидні засоби & Зниження абсорбції 1 \\
Триметоприм & Холестирамін & \\
Кліндаміцин & & \\
Цефалексин & & Зниження абсорбції 1 \\
Тетрациклін & & \\
Тироксин & & \\
\hline
\end{tabular}

Таблиця 6. Результати взаємодії з лікарськими засобами, які знижують кислотність шлункового вмісту (Белоусов Ю.Б., Гуревич К.Г., 2005, зі змінами)

\begin{tabular}{|c|c|c|}
\hline Препарат 1 & Препарат 2 & $\begin{array}{c}\text { Результати } \\
\text { взаємодії }\end{array}$ \\
\hline $\begin{array}{l}\text { Антациди } \\
\text { Інгібітори протонної } \\
\text { помпи } \\
\text { Н } \text {-гістаміноблокатори }\end{array}$ & $\begin{array}{l}\text { Слабкі кислоти (саліцилати, } \\
\text { барбітурати, кислота налідиксова, } \\
\text { антибактеріальні та антидіабетичні } \\
\text { сульфаніламіди, індометацин, } \\
\text { непрямі антикоагулянти, клофібрат) }\end{array}$ & $\begin{array}{l}\text { Зниження всмоктуван- } \\
\text { ня препаратів } 2\end{array}$ \\
\hline $\begin{array}{l}\text { Антациди } \\
\text { Інгібітори протонної } \\
\text { помпи } \\
\text { H }_{2} \text {-гістаміноблокатори }\end{array}$ & Сукральфат & $\begin{array}{l}\text { Порушення утворення } \\
\text { захисної плівки, } \\
\text { зменшення ефекту } \\
\text { препарату } 2\end{array}$ \\
\hline Адссорбенти & $\begin{array}{l}\text { Кетоконазол } \\
\text { Лансопразол } \\
\text { Серцеві глікозиди } \\
\text { Тетрацикліни } \\
\text { Гормони щитоподібної залози } \\
\text { Фенітоїн } \\
\text { Фторхінолони }\end{array}$ & $\begin{array}{l}\text { Зниження всмоктуван- } \\
\text { ня препаратів } 2\end{array}$ \\
\hline
\end{tabular}

Таблиця 7. Взаємодія гормональних контрацептивів з іншими лікарськими засобами (Белоусов Ю.Б., Гуревич К.Г., 2005; Дроговоз С.М. и соавт., 2010)

Препарат 1, 3 яким взаємодіє контрацептив

Результат взаємодії

Трициклічні антидепресанти, глюкокортикостероїди, непрямі антикоагулянти

Антигіпертензивні засоби Зниження ефективності препарату 1

Протидіабетичні препарати

Зниження ефективності препарату 1 за рахунок підвищення активності реніну Зниження ефективності препарату 1 Зниження активності контрацептивів (пригнічення кишкової мікрофлори) Антибіотики Зниження активності контрацептивів карбамазепін, рифампіцин, рифабутин, (прискорення їх метаболізму) фелбамат, гризеофульвін, звіробій) Інгібітори ВІЛ-протеази (ритонавір), ненуклеозидні інгібітори зворотної Зниження активності контрацептивів транскриптази (невірапін) 
тивність лікарських засобів може знижуватися також внаслідок розвитку дисбактеріозу.

У деяких випадках несприятливі наслідки взаємодії лікарських засобів при їх комбінованому застосуванні мають особливе, життє во важливе значення. Зокрема, зменшення гіпоглікемічної дії інсуліну може відбутися під впливом симпатоміметиків, естрогенів, глюкокортикостероїдів, глюкагону, дифеніну, бензотіадіазинових діуретиків, солей літію (Белоусов Ю.Б., Гуревич К.Г., 2005; Дроговоз С.М. и соавт., 2010). У табл. 7 представлені результати взаємодії гормональних контрацептивів з іншими лікарськими засобами, що супроводжується зниженням їх ефективності і, відповідно, зростанням імовірності виникнення незапланованої вагітності (це особливо небажано утому разі, якщо жінка хворіє на туберкульоз або ВІЛ-інфікована, що потребує тривалого застосування препаратів, які можуть зашкодити майбутній дитині).

Взаємодія лікарських засобів може відбуватись на етапі їх метаболізму. При цьому під впливом індукторів мікросомальної ферментної системи гепатоцитів прискорюється біотрансформація і зменшується фармакологічна активність тих лікарських засобів, метаболізм яких насамперед здійснюється системою цитохрому Р450 (Арчаков А.И., 1983; Бажора Ю.І., 2003; Коржов В.И. и соавт., 2007; Яковлева О.О. та співавт., 2011).

Відомо близько 300 лікарських засобів та інших хімічних сполук, що здатні підвищувати активність цієї системи (Скакун Н.П., 1981; Чекман И.С. и соавт., 1996; Самура Б.А. (ред.), 2009). Незважаючи на широку субстратну специфічність різних ізоформ цитохрому Р450, деякі ліки переважно метаболізуються певною ізоформою цього ферменту. Зокрема, понад 50\% відомих лікарських засобів метаболізуються ізоформою цитохрому Р450 3А4. Активуючий вплив індукторів ферментів мікросом також маєпевну вибірковість (табл. 8)

Потужну стимулювальну дію на ферменти мікросом можуть зумовлювати офіцинальні препарати звіробою, які ефективні при депресії легкої та середньої тяжкості, чи настої з цієї рослини, які часто використовують для самолікування при порушеннях функції органів травлення (Ташенова А.И., 2010; Посохова К.А., 2017). Звіробій підвищує активність цитохромів Р450 3А4, P450 2E1 та Р450 2C19. Водночас він підвищує активність Р-глікопротеїну (захисного чинника, що сприяє транспорту лікарських засобів упросвіт кишечнику, жовчні протоки, канальці нирок, капіляри мозку та інших органів через ендотелій гістогематичних бар'єрів). Субстратами цитохрому Р450 3А4 і Р-глікопротеїну є протипухлинні засоби (іринотекан, іматиніб, вінкристин, доцетаксел, паклітаксел, фінастерид, тамоксифен), серцеві глікозиди (дигоксин), бета-блокатори (талінолол), антигістамінні засоби, імунодепресанти (циклоспорин, такролімус), непрямі антикоагулянти (варфарин, фенпрокумон, феніндіон, аценокумарол), гормональні контрацептиви, блокатори кальцієвих каналів (верапаміл, ніфедипін), антиретровірусні препарати (індинавір, ламівудин, невірапін), бензодіазепіни (альпразолам, мідазолам, буспірон), статини, кларитроміцин, левофлоксацин, кетоконазол (Ташенова А.И., 2010). При комбінуванні препаратів звіробою з цими лікарськими засобами їх метаболізм та виведення з органів-мішеней може відбуватись інтенсивніше, а ефективність суттєво знижуватись. Індуктивний вплив на Р-глікопротеїн також проявляють рифампіцин, дексаметазон, морфін, ретиноїди, фенобарбітал, фенотіазини та ін. При їх комбінуванні з ліками - субстратами Р-глікопротеїну знижується ефективна концентрація останніх в органах-мішенях (Ташенова А.И., 2010).

На противагу індуктивному впливові, інгібітори цитохрому Р450 можуть знижувати ефективність лікарських засобів, які належать до проліків (табл. 9).

Ще один фактор, що може впливати на ефективність фармакотерапії, це ступінь реабсорбції ліків у ниркових канальцях залежно від рН сечі (табл. 10). Цей процес може пригнічуватися для ліків - слабких кислот при лужній реакції сечі та навпаки.

Зниження ефективності лікарських засобів може статися з причини неврахування циркадних змін деяких фармакокінетичних процесів (Ede M.C.M., 1973). На етапі всмоктування - це добові коливання рН шлункового соку, активності абсорбції у тонкому кишечнику. Під час розподілу лікарських засобів - це ступінь зв'язування з білками крові, інтенсивність кровообігу, властивості клітинних рецепторів. Метаболізм та елімінація лікарських засобів також можуть змінюватися протягом доби. Зокрема, відбуваються зміни активності цитохрому Р450, рН сечі, ниркового та печінкового кліренсу. Так, сечогінні лікарські засоби діють інтенсивніше при застосуванні зранку. Ефективність антидепресантів змінюється залежно від часу доби (Белоусов Ю.Б., Гуревич К.Г., 2005; Иванов А.М. и соавт., 2010б). Встановлено, що пароксетин, піпофезен, тетриндол, флуоксетин ефективніші при їх застосуванні зранку чи вдень. Доксепін, міансерин, міртазапін, триміпрамін, флувоксамін доцільніше застосовувати ввечері. А ефективність альпразоламу, амітриптиліну, іміпраміну, кломіпраміну, мапротиліну, мілнаципраму, моклобеміду, приліндолу, сертраліну, тіанептину, тазодону, циталопраму не залежить від часу доби.

На особливу увагу заслуговує зниження чи відсутність ефективності антиінфекційних лікарських засобів (антибактеріальних, антимікобактеріальних, противірусних, протигрибкових тощо). На жаль, ця проблема набула світового масштабу і на сьогодні знаходиться у зоні нагляду Всесвітньої організації охорони здоров'я (ВООЗ). Випадки смерті від гострих респіраторних інфекцій, захворювань, що супроводжуються діареєю, кору, СНІДу, малярії та туберкульозу становлять понад 85\% смертності від інфекцій в усьому світі. Разом з тим стійкість до препаратів першого ряду у більшості патогенних мікроорганізмів, що спричинюють ці захворювання, коливається від нуля до майже 100\%. У деяких випадках стійкість інфекційних збудників до лікарських засобів другого і третього ряду впливає на результати лікування, суттєво зменшуючи їх. Окрім того, людству загрожують такі глобальні проблеми, як висока резистентність збудників нозокоміальних інфекцій (особливо представників родини Enterobacteriaceae - продуцентів бета-лактамаз розширеного спектра дії), стійкість до противірусних препаратів, зростання резистентності до лікарських засобів, що використовують при задавнених паразитарних захворюваннях.

Таблиця 8. Субстрати та індуктори певних ізоформ цитохрому Р450 (Яковлева 0.О. та співавт., 2011; Воловикова О.Н., Михайлова Е.И., 2012)

\begin{tabular}{|c|c|c|}
\hline $\begin{array}{l}\text { Ізоформа } \\
\text { цитохрому } \\
\text { P450 }\end{array}$ & Індуктори & Субстрати \\
\hline $3 \mathrm{~A} 4$ & $\begin{array}{l}\text { Барбітурати, карбамазе- } \\
\text { пін, ампренавір, } \\
\text { ритонавір, ефавіренз, } \\
\text { дексаметазон, фенітоїн, } \\
\text { піоглітазон, рифампіцин, } \\
\text { рифабутин, звіробій }\end{array}$ & $\begin{array}{l}\text { Аміодарон, аторвастатин, ловастатин, } \\
\text { карбамазепін, цизаприд, кларитроміцин, } \\
\text { еритроміцин, циклоспорин, антагоністи Са } \\
\text { дигідропіридинового ряду, дилтіазем, } \\
\text { естрогени, прогестерон, інгібітори протеази } \\
\text { ВІЛ, рифампіцин, симвастатин, тестостерон }\end{array}$ \\
\hline $1 \mathrm{~A} 2$ & $\begin{array}{l}\text { Рифампіцин, ритонавір, } \\
\text { нікотин, капуста броколі, } \\
\text { капуста брюсельська, } \\
\text { м'ясо, смажене на грилі }\end{array}$ & $\begin{array}{l}\text { Кофеїн, клозапін, оланзапін, галоперидол, } \\
\text { варфарин, пропранолол, теофілін, } \\
\text { трициклічні антидепресанти, зилеутон }\end{array}$ \\
\hline $2 \mathrm{Cg}$ & Рифампіцин & $\begin{array}{l}\text { Амітриптилін, диклофенак, флувастатин, } \\
\text { ібупрофен, ірбесартан, лозартан, напроксен, } \\
\text { піроксикам, фенітоїн, варфарин, вальпроєва } \\
\text { кислота }\end{array}$ \\
\hline
\end{tabular}

Таблиця 9. Вплив інгібіторів ферментів мікросом на фармакокінетику деяких проліків (Белоусов Ю.Б., Гуревич К.Г., 2005; Журавлева М.В. и соавт., 2015; Комаров А.Л., 2015, зі змінами)

\begin{tabular}{lcc}
\multicolumn{1}{c}{ Препарат 1 } & Інгібітори цитохрому P450 & Метаболізм 1 \\
\hline Еналаприл & Омепразол & \\
Лізиноприл & Флуконазол & \\
Цилазаприл & Кетоконазол & \\
Раміприл & Вориконазол & \\
Трамадол & Флуоксетин & \\
Лозартан & Флувоксамін & Сповільнення утворення \\
Клопідогрель & та ін. & \\
Кодеїн & & \\
Спіронолактон & & \\
Азатіоприн & & \\
Примідон & & \\
Тамоксифаболіту \\
\hline
\end{tabular}

Таблиця 10. Лікарські засоби, реабсорбція яких у канальцях нирок пригнічується при певному $\mathrm{pH}$ сечі

\begin{tabular}{lc}
\hline \multicolumn{1}{c}{ Кисла реакція сечі } & Лужна реакція сечі \\
\hline Кодеїн & Барбітурати \\
Морфін & Саліцилати \\
Новокаїн & Сульфаніламіди \\
Хінін & Нітрофурани \\
Хлорохін & Амінокислоти \\
Амфетамін & Налідиксова кислота \\
Іміпрамін & \\
Цефалоспорини & \\
\hline
\end{tabular}


У цих умовахГлобальна стратегія ВООЗ щодо стримування стійкості до протимікробних препаратів складається з низки заходів, що сприятимуть уповільненню виникнення і обмеженню поширення стійких штамів мікроорганізмів шляхом:

- впровадження заходів, що сприятимуть зниженню захворюваності й поширення інфекцій;

- поліпшення доступу до необхідних протимікробних препаратів;

- забезпечення раціонального застосування протимікробнихпрепаратів;

- посилення систем охорони здоров'я та їх здатності до контролю за поширенням резистентності;

- зміцнення регулювання і законодавства;

- підтримка створення відповідних нових лікарських засобів і вакцин (World Health Organization, 2001).

За статистикою антибіотики становлять $25 \%$ усіх лікарських засобів, які застосовують в Україні. При цьому у кожному другому випадку їх призначають невиправдано чи приймають без рекомендації лікаря. За вітчизняними даними 2011-2012рр., рівень стійкості мікроорганізмів до найсучаснішихантибіотиків, хоча й істотно коливається залежно від області, міста, конкретного лікувального закладу, але у багатьох випадках перевищує 25-50\%, нерідко сягаючи 100\% (Karlson B. et al., 1986; Фещенко Ю.І. та співавт., 2010; Лазоришинець В.В. та співавт., 2011; Марієвський В.Ф. та співавт., 2011; Oliynyk O.V. etal., 2016). Встановлено, що $(70,70 \pm 0,76) \%$ штамів умовнопатогенних мікроорганізмів (УПМ) - збудників післяопераційних гнійно-запальнихінфекцій - резистентні щонайменшедо двохантимікробних препаратів. Кількість штамів УПМ, резистентних до двох і більше класів антимікробних препаратів (мультирезистентні штами мікроорганізмів), становить у середньому $(34,40 \pm 0,09) \%$ (Салманов А.Г., 2015)

Усвідомлення актуальності проблеми стійкості мікроорганізмів стало важливим поштовхом до розпочатого у 2010 р. вивчення рівня споживання протимікробних лікарських засобів в Україні та удосконалення системи епіднагляду за антибіотикорезистентністю.

У разі ВЕ антимікробного лікарського засобу без спеціальних додаткових досліджень важко зробити висновок - що це: наслідок неналежної якості лікарського засобу чи результат резистентност мікроорганізмів. Допомогти вирішенню цього питання може вчасно зроблене визначення чутливості мікроорганізмів, виділених від даного пацієнта (забір матеріалудля дослідження проводиться обов'язково до першого призначення антиінфекційного агента!). 3 іншого боку, особливого значення набуває регулярний моніторинг випадків ВЕантимікробних лікарських засобів (фахівцями з медичною та фармацевтичною освітою), оскільки дозволяє зробити висновок про рівень резистентності збудників інфекційних процесів, про тенденції її прогресуючого зростання у закладах охорони здоров'я України та розробити заходи з ії мінімізації.

Ще один важливий аспект, який необхідно враховувати при оцінці ефективності деяких груп лікарських засобів, це ймовірність ї зниження під впливом компонентів їжі (Белоусов Ю.Б., Гуревич К.Г., 2005; Зборовский А.Б. и соавт., 2008). Так, при прийомі непрямих антикоагулянтів, зокрема варфарину, не слід вживати продукти, що містять велику кількість вітаміну К, а саме: яловичу печінку, зелен овочі (всі види капусти, шпинат, петрушку, кріп, спаржу, салати, огірки, зелену цибулю), горіхи (особливо грецькі), чорнослив, бобові, кабачки тощо, оскільки вітамін К протидіє розвитку ефекту цих препаратів, що супроводжується зростанням ризику утворення тромбів (Lee M. et al., 1981; Kempin S.J., 1983; Karlson B. et al., 1986; Pedersen F.M. et al., 1991; Посохова К.А., 2017).

Прискорити біотрансформацію варфаринуі, відповідно, знизити його ефективність можуть соя та продукти з неї, що активують ферменти мікросомальної системи печінки (Cambria-Kiely J.A., 2002). Слід зауважити, що сьогодні в Україні соя та соєве молоко нерідко використовуються як компонент різноманітнихготовихвиробів харчування, з них виробляють сир тофу, кефір, бульйон, йогурти, молочн коктейлі, а також використовують для приготування випічки. Тому пацієнтам, які приймають непрямі антикоагулянти, необхідно зважати на цей факт і проявляти обережність при споживанні продуктів такого типу.

Такі напої, як фанта, пепсі-кола, містять значну кількість іонів кальцію, заліза, що утворюють нерозчинні комплекси з антибіотиками групи тетрациклінів, макролідів, фторхінолонів, що призводить до зниження їх антибактеріальної активності. Танін, що міститься
Таблиця 11. Результати взаємодії деяких лікарських засобів і компонентів тютюнового диму (Белоусов Ю.Б., Гуревич К.Г., 2005)

$$
\text { Препарат }
$$

Результат взаємодіі

Іміпрамін, кломіпрамін, флувоксамін, тразодон, Зростання швидкості метаболізму, дезіпрамін, триміпрамін, мексилетин Галоперидол, хлорпротиксен, клозапін, оланзепін, альпразолам, лоразепам,

оксазепам, діазепам

Теофілін, кофеїн, метопролол, нітрати, естрадіол, пропранолол

Гепарин

Блокатори бета-адренорецепторів зниження ефективності Підвищення кліренсу, зниження ефективності

Зниження концентрації препаратів в крові, зменшення ефективності Зростання швидкості метаболізму, зменшення антикоагулянтної дії Зменшення ефективності впливу препаратів на серцевий ритм

увеликій кількості у свіжозавареному міцному чаї, зменшує швидкість і ступінь всмоктування атропіну, кодеїну, морфіну, папаверину, платифіліну, аміназину, галоперидолу, пероральних контрацептивів. Молоко знижує біодоступність тетрациклінів, цефалоспоринів, фторхінолонів, деяких антиретровірусних препаратів (нелфінавіру). Зниження антипаркінсонічної активності леводопи можливе у разі її комбінування з продуктами, що містять вітамін В (авокадо, боби, яловича та свиняча печінка, горох, тунець, соя тощо). Їжа, багата на клітковину, може порушити всмоктування серцевих глікозидів, антидепресантів. При запиванні лужною мінеральною водою лікарських засобів із кислотостійким покриттям відбувається руйнування захисної оболонки i, відповідно, зниження ефективності. При вживанні продуктів, що олужнюють сечу (овочі, фрукти, молоко), зростає нирковий кліренс лікарських засобів - слабких кислот (саліцилатів, барбітуратів). Надмірне вживання харчової солі призводить до зниження ефективностіпрепаратів літію, бромідів внаслідок збільшення їх виділення з сечею (Белоусов Ю.Б., Гуревич К.Г., 2005; Зборовский А.Б. и соавт., 2008).

Фармакокінетика лікарських засобів залежить від впливу алкоголю та кратності його вживання (Скакун Н.П., 1985). Як відомо, одноразовий прийом цього токсичного агента пригнічує активність ферментів мікросом зі зростанням ризикупроявів токсичності лікарських засобів при поєднаному їх застосування. Проте в алкоголіків відбувається наростання активності печінкової системи метаболізму, що призводить до прискорення біотрансформації лікарських засобів. Осьчомув цих осібуперіодтверезості можлива толерантністьдопротисудомних препаратів, гепарину та непрямих антикоагулянтів, протидіабетичнихлікарськихзасобів, діуретиків, серцевихглікозидів, нітратів, засобів для наркозу, місцевих анестетиків амідної групи.

Негативний вплив на ефективність лікарських засобів мають іпродукти тютюнового диму, які здатні індукувати цитохром P450 1А2 (табл. 11).

Крім того, нікотин за рахунок стимуляції Н-холінорецепторів різної локалізації (симпатичнихгангліїв, мозкового шарунадниркових залоз) спричиняє зростання артеріального тиску, тому укурців може суттєво знижуватись ефективність антигіпертензивної фармакотерапії.

Зважаючи на те що проблема ВЕ лікарських засобів може виникнути з багатьох причин, на думку авторів, у їі вирішенні суттєву роль відіграють дві ключові фігури - лікар іпацієнт, а особливого значення набуває процес комунікації між ними. 3 одного боку, здатність уникнути BE лікарських засобів залежить від знань лікаря про лікарські засоби, від того, що йому відомо про пацієнта, а також - від його бажання та вміння лікувати та донести до пацієнта інформацію про лікарський засіб, особливості його застосування, несприятливі наслідки лікування та шляхи їх уникнення чи мінімізації. 3 іншого боку, запобігти BE препаратів можна за певної позиції пацієнта щодо застосування лікарських засобів, його здатності усвідомлювати отриману від лікаря інформацію, прихильності до виконання його рекомендацій та унеможливлення намагань самотужки лікуватися чи коригувати призначену фармакотерапію. Надзвичайно важливим $€$ державний підхід до вивчення та вирішення проблеми ВЕ антимікробних лікарських засобів. Сподіваємося, що поєднання зусиль усіх учасників процесу лікування (за наявності існуючих знань та доказів щодо ефективності та безпеки застосування лікарських засобів) допоможе вирішенню проблеми ВЕ лікарських засобів.

Список використаної літератури

Арчаков А.И. (1983) Оксигеназы биологических мембран. 37-е Баховское чтение. Наука, Москва, 56 с. 

$140 \mathrm{c}$

Бажора Ю.І. (2003) Фармакогенетика: досягнення і перспективи. Друк, Одеса

Барышева В.О., Кетова Г.Г. (2016) Персонализированная медицина: реализация фармакогенетики в практике. Непрерывное медицинское образование и наука, 11(1): 4-7.

Белоусов Ю.Б., Гуревич К.Г. (2005) Клиническая фармакокинетика. Практика дозирования лекарств: Спец. выпуск серии «Рациональная фармакотерапия» Литтерра, Москва, 288 с.

Боброва О.П., Шнайдер Н.А., Зырянов С.К. (2017) Молекулярная диагностика полиморфизма генов биотрансформации опиоидных анальгетиков и ее роль в изучении модификационной изменчивости обезболивания в клинической онкологии В кн.: Молекулярная діагностика, Т. 1. Фармакогенетика и фармакогеномика, c. 519-520.

Воловикова О.Н., Михайлова Е.И. (2012) Роль фармакогенетики в развитии персонализированной медицины при заболеваниях внутренних органов (обзор литературы). Проблемы здоровья и экологии, 2(32): 13-18.

Дроговоз С.М., Гудзенко А.П., Бутко Я.А., Дроговоз В.В. (2010) Побочное действие лекарств: Учебник-справочник. СИМ, Харьков, 480 с.

Журавлева М.В., Кукес В.Г., Прокофьев А.Б. и др. (2015) Эффективность и безопасность применения лекарственных средств: значение и возможности кли нической фармакологии. Ведомости Научного центра экспертизы средств медицинского применения, 2: 20-24.

Зборовский А.Б., Тюренков И.Н., Белоусов Ю.Б. и др. (2008) Неблагоприятные побочные эффекты лекарственных средств. Медицинское информационное агентство, Москва, 656 с

Иванов А.М., Камилова Т.А., Довгополюк А.Б., Абриталин Е.Ю. (2010а) Фармакогенетика в психиатрии: антидепрессанты. Вест. Рос. воен.-мед. акад., 2 201-210.

Иванов А.М., Камилова Т.А. , Довгополюк А.Б. , Абриталин Е.Ю. (2010б) Фармакогенетика в психиатрии: нейролептики. Вест. Рос. воен.-мед. акад., 3 238-245.

Комаров А.Л. (2015) Оценка чувствительности к клопидогрелу: современное состояние проблемы. Атеротромбоз, 2: 95-106.

Коржов В.И., Жадан В.Н., Коржов М.В. (2007) Роль системы глутатиона в процессах детоксикации и антиоксидантной защиты. Журн. АМН України, 13(1): 3-19.

Кравченко І.А. (2005) Фармакогеноміка з основами фармакогенетики: Навч. пос. Астропринт, Одеса, 144 с.

Лазоришинець В.В., Хобзей М.К., Марієвський В.Ф. та ін. (2011) Антибіотикорезистентність клінічних штамів Enterobacter spp. в хірургічних стаціонарах Україні в 2010 р. Ліки України, 1(5): 34-38.

Марієвський В.Ф., Салманов А.Г., Хобзей Н.К., Зозуля И.С. (2011) Антибіотикорезистентність клінічних штамів Enterococcus faecalis у хірургічних стаціонарах України в 2010р. Укр. мед. часоп., 3(83): 119-122.

Матвєєва О., Яйченя В. (2014) Отсутствие эффективности лекарственного средства или медицинская ошибка? Медична газета України «Ваше здоров'я», с. 7-8.

Махарин О.А., Макляков Ю.С., Женило В.М. (2012) Полиморфизм генов системы детоксикации ксенобиотиков и его роль в биотрансформации внутривенных анестетиков. Биомедицина, 1(1-3): 98-107.

Мельник А.А. (2016) Применение фармакогенотипирования и дозирование некоторых препаратов в урологии и нефрологии. Почки, 1(15): 96-104.

Панчишин Ю..М., Якубенко Ю.П. (2011) Статини: плюси та мінуси. Рац. фармакотер., 1(18): 47-56

Посохова К.А. (2017) Як харчуватися при лікуванні варфарином. Рац. фармакотер., 2(43): 12-17.

Рэнки П.Дж., Рэнки Р.Г., Джон Э., Рэнки Г.Н. (2014) Влияние упаковки на стабильность лекарственных препаратов. Фармац. технол. упак., 6(244): 62-65.

Садвакас А.C. (2014) Pharmacogenetics of drug transporters. Наука 21 века: вопросы, гипотезы, ответы, 4: 55-60.

Салманов А.Г. (2015) Антимікробна резистентність та інфекції, асоційовані 3 медичною допомогою в Україні. Епідеміологічний звіт мультицентрового дослідження (2010-2014рр.). Агшрар Медіа груп, Київ, 452 с

Самура Б.А. (ред.) (2009) Загальна фармакокінетика. ТДМУ, Тернопіль, 356 с

Сидоренко И.А., Галаева Я.Ю., Налетов С.В., Конышева Н.В. (2017) Фармакогенетика и фармакотерапия: общие вопросы. Ун-тетская клиника, 12(1): 89-93.

Скакун Н.П. (1981) Клиническая фармакогенетика. Здоров'я, Київ, 200 с.

Скакун Н.П., Саратиков А.С., Олейник А.Н., Венгеровский А.И. (1985) Этиловый алкоголь (фармакокинетика, взаимодействие с лекарствами, гепатотоксичность). Изд-во Томск. ун-та, Томск, 135 с.

Сычев Д.А., Игнатьев И.В., Емельянов Н.В. и др. (2009) Фармакогенетическое тестирование: первые шаги в реальной клинической практике и проблемы стандартизации. Проблемы стандартизации в здравоохранении, 1: 43-55.

Ташенова А.И. (2010) Транспортная система гликопротеина-Р и фармакокинетика лекарственных средств. Биомедицина, 1(4): 24-32.

Фещенко Ю.І. , Гуменюк М.І. , Денисов О.С. (2010) Антибіотикорезистентність мікроорганізмів. Стан проблеми та шляхи її вирішення. Укр. хіміотер. журн., 23(12): 4-10.

Чекман И.С., Посохова Е.А., Береговая Е.Г. (1996) Микросомальная ферментная система организма. Киев-Запорожье, 80 с.
Яковлева О.О., Коновалова Н.В., Косован А.І. та ін. (2011) Клінічна фармакогенетика: Навч. посіб. Нова книга, Вінниця, 160 с.

Cambria-Kiely J.A. (2002) Effect of soy milk on warfarin efficacy. Ann. Pharmacother., 36(12): 1893-1896.

Ede M.C.M. (1973) Circadian rhythms of drug effectiveness and toxicity. Clin. Pharm. Therap., 14(6): 925-935.

Food and Drug Administration US (2016) Table of pharmacogenomic biomarkers in drug labeling [2015-07-29].

http://www.fda.gov/Drugs/ScienceResearch/ResearchAreas/Pharmacogenetics/ucm 083378. htm

Hider S.L. , Bruce I.N., Thomson W. (2007) The pharmacogenetics of methotrexate. Rheumatology, 46(10): 1520-1524

Karlson B., Leijd B., Hellström K. (1986) On the influence of vitamin K-rich vegetables and wine on the effectiveness of warfarin treatment. J. Inter. Med., 220(4): 347-350.

Kempin S.J. (1983) Warfarin resistance caused by broccoli. New Engl. J. Med., 308(20): 1229-1230.

Lee M., Schwartz R.N., Sharifi R. (1981) Warfarin resistance and vitamin K. Ann. Inter. Med., 94(1): 140-141.

Martens H.J., De Goede P.N., Van Loenen A.C. (1990) Sorption of various drugs in polyvinyl chloride, glass, and polyethylene-lined infusion containers. Am. J. Health-Syst. Pharm., 47(2): 369-373.

Oliynyk O.V., Titov I.I., Pereviznyk B. (2016) Epidemiology of severe sepsis caused by severe craniocerebral trauma in Western Ukraine. Hospital surgery, 1(1): 44-50.

Pedersen F.M., Hamberg 0., Hess K., Ovesen L. (1991) The effect of dietary vitamin K on warfarin-induced anticoagulation. J. Intern. Med., 229(6): 517-520.

Seifi A., Mowla A., Vaziri M.M. et al. (2004) Insulin adsorbance to polyvinylchloride (PVC) surfaces of fluid container and infusion-set. Mid. East J. Anaesthesiol., 17(5): 975-981.

Thompson C., Vital-Carona J., Faustino E.V.S. (2012) The effect of tubing dwell time on insulin adsorption during intravenous insulin infusions. Diabet. Technol. Therapeut., 14(10): 912-916.

Weir S.J., Myers V.A., Bengtson K.D., Ueda C.T. (1985) Sorption of amiodarone to polyvinyl chloride infusion bags and administration sets. Am. J. Health-Syst. Pharm., 42(12): 2679-2683.

World Health Organization (2001) WHO global strategy for containment of antimicrobial resistance: executive summary (WHO/CDS/CSR/DRS/2001.2).

\section{Влияние индивидуальных особенностей организма, патологических} процессов, комбинированного применения лекарственных средств на их эффективность

\section{Е.А. Посохова, Е.В. Матвеева}

Резюме. Анализируются причины снижения (отсутствия) эффективности лекарственных средств: генетически обусловленные особенности пациента, влияние коморбидных патологических процессов, последствия взаимодействия лекарственных средств при их комбинированном применении, их взаимодействие с пищевыми продуктами, влияние табакокурения, резистентность инфекционного возбудителя к антимикробному препарату.

Ключевые слова: лекарственные средства, отсутствиеэффективности.

Impact of individual characteristics of an organism, pathological processes, and combined administration of medicinal products on their efficacy

\section{K.A. Posokhova, O.V. Matvieieva}

Summary. The causes for the decrease (absence) of effectiveness of medicinal products are analyzed: genetically determined characteristics of a patient, effects of comorbid pathological processes, consequences of drug interaction in their combined use, their interaction with food products, effects of smoking, infectious agents' resistance to antimicrobial drugs.

Key words: medicines, lack of effectiveness.

Адреса для листування:

Посохова Катерина Андріївна

E-mail: kposokhova@gmail.com

Матвєєва Олена Валеріївна

E-mail: matveeva@dec.gov.ua 